\title{
COMPARISON OF INDUCTION CHARACTERISTICS OF PROPOFOL AND THIOPENTONE IN ENT SURGERY IN CHILDREN
}

\author{
Setty Arumugam Namasivayam ${ }^{1}$, Mariappan Gomathi', Raju Sudhakar ${ }^{3}$
}

${ }^{1}$ Associate Professor, Department of Anaesthesiology, Government Vellore Medical College Hospital, Adukkamparai, Vellore. ${ }^{2}$ Associate Professor, Department of Anaesthesiology, Government Vellore Medical College Hospital, Adukkamparai, Vellore. ${ }^{3}$ Associate Professor, Department of Anaesthesiology, Government Vellore Medical College Hospital, Adukkamparai, Vellore.

\begin{abstract}
BACKGROUND

Induction of general anaesthesia in children(1) is accomplished by either intravenous or inhalations route or rarely by the rectal route. The choice will depend on the anaesthetist's preference, the ease of venous puncture and the child's level of co-operation, sedation and clinical condition. Intravenous agents(2) are used more commonly than inhalational agents to induce anaesthesia, as induction is more rapid and smoother. Inj. Propofol and Inj. Thiopentone sodium are common intravenous induction agents in our hospital.

The aim of the study was to compare the induction characteristics of Inj. Thiopentone and Inj. Propofol in premedicated children namely,

1. Onset time of induction of general anaesthesia.

2. Haemodynamic changes(3) during induction.

\section{MATERIALS AND METHODS}

This prospective clinical study was conducted at Government Vellore Medical College, Adukkamparai, Vellore in 50 patients aged between 6 to 10 yrs. undergoing tonsillectomy and adenoidectomy. They were divided into 2 groups of 25 each. Group P: children who received propofol $3 \mathrm{mg} / \mathrm{kg}$ gas induction agent. Group T: children who received thiopentone(4) $5 \mathrm{mg} / \mathrm{kg}$ as induction agent. Preinduction and post-induction parameters like onset of induction time, blood pressure, heart rate, incidence of apnoea, etc. were recorded. In analysing the data student's 'L' test, chi-squared test with Yates correction for small numbers were used where appropriate. $P$ value $\leq 0.01$ is considered statistically significant.
\end{abstract}

\section{RESULTS}

The mean age, weights and sex of the patients were similar in both groups. The mean induction time in Group $\mathrm{P}$ was $36.8 \pm 7.90$ seconds and in Group T was 29 \pm 3.44 seconds and the difference is not statistically significant. In Group T, mean systolic pressure increased from $112 \pm 4.8 \mathrm{mmHg}$ to $117 \pm 4.2 \mathrm{mmHg}$ during the second minute and $99 \pm 3.2 \mathrm{mmHg}$ at 10 th minute. In Group $\mathrm{P}$, mean systolic pressure reduced from $112 \pm 4.8 \mathrm{mmHg}$ to $102 \pm 4.4 \mathrm{mmHg}$ during the second minute and $91 \pm 2.8 \mathrm{mmHg}$ at 10 th minute and the reduction is statistically significant. Following induction and intubation, the mean diastolic pressure in Group $\mathrm{T}$ increased from $73 \pm 4.7 \mathrm{mmHg}$ to $79 \pm 4.3 \mathrm{mmHg}$ in the second minute and $62 \pm 3.2 \mathrm{mmHg}$ in the 10 th minute. In Group P, the mean diastolic pressure fell from $70 \pm 4.6 \mathrm{mmHg}$ to $66 \pm 4.8 \mathrm{mmHg}$ in the second minute and $58 \pm 2.2 \mathrm{mmHg}$ in the 10th minute. The fall in mean diastolic pressure was greater in Group P, statistically significant $(\mathrm{p}<0.01)$. Mean arterial pressure in Group T increased from $86 \pm 4.7 \mathrm{mmHg}$ to $91 \pm 4.6 \mathrm{mmHg}$ in the second minute. In Group P, the mean arterial pressure fell from $84 \pm 4.6 \mathrm{mmHg}$ to $77 \pm 5.2 \mathrm{mmHg}$ in the second minute. The fall in mean systolic pressure in Group $\mathrm{P}$ is statistically significant $(\mathrm{P}=0.01)$. The pre-induction mean pulse rate Group $\mathrm{T}$ was $110 \pm 4.5$ per minute, while pre-induction mean pulse rate Group P was $116 \pm 4.7$ per minute. The mean pulse rate in Group $P$ reduced to $108 \pm 4.6$ per minute in the second minute and gradually reached $100 \pm 4.4$ per minute in 10 minutes. The mean pulse rate in Group $\mathrm{T}$ increased to $118 \pm 4.4$ per minute in the second minute and gradually reached $100 \pm 3.2$ per minute in 10 minutes. The mean decrease in pulse rate in Group $P$ is statistically significant $(\mathrm{P} \leq 0.01)$.

\section{CONCLUSION}

For both induction agents Thiopentone and Propofol, the onset time was similar. Induction with Propofol produced a significant fall in haemodynamic variables like heart rate and blood pressures than Thiopentone.

\section{KEYWORDS}

Induction, Propofol, Thiopentone, Paediatric.

HOW TO CITE THIS ARTICLE: Namasivayam SA, Gomathi M, Sudhakar R. Comparison of induction characteristics of propofol and thiopentone in ENT surgery in children. J. Evolution Med. Dent. Sci. 2016;5(102):7469-7473, DOI: 10.14260/jemds/2016/1691

Financial or Other, Competing Interest: None.

Submission 28-09-2016, Peer Review 10-12-2016,

Acceptance 16-12-2016, Published 22-12-2016.

Corresponding Author:

Setty Arumugam Namasivayam,

Department of Anaesthesiology,

Government Vellore Medical College Hospital,

Adukkamparai, Vellore-632011

E-mail: sanamasivayam@gmail.com

DOI: $10.14260 /$ jemds/2016/1691

\section{BACKGROUND}

Induction of general anaesthesia in children is accomplished by either intravenous or inhalations route or rarely by the rectal route. The choice will depend on the anaesthetist's preference, the ease of venepuncture and the child's level of co-operation, sedation and clinical condition.

Intravenous agents are used more commonly than inhalational agents to induce anaesthesia as induction is more rapid and smoother. Inj. Propofol(5) and Inj. Thiopentone 
sodium are common intravenous induction agents in our hospital.

\section{Aim of Study}

The aim of the study was to compare the induction characteristics of Inj. Thiopentone and Inj. Propofol in premedicated children namely,

1. Onset time of induction of general anaesthesia.(6)(7)

2. Haemodynamic changes during induction.

\section{MATERIALS AND METHODS}

This prospective clinical study was conducted at Government Vellore Medical College, Adukkamparai, Vellore in 50 patients aged between 6 to 10 yrs. undergoing elective surgery with duration lasting less than one hour.

A total of 50 paediatric patients who underwent tonsillectomy and adenoidectomy were randomly divided into 2 groups of 25 each.

Group P - Those who received propofol induction agent.

Group T - Those who received thiopentone as induction agent.

\section{Inclusion Criteria}

1. Patients of either sex aged 6 to 10 years.

2. ASA I and II.

3. Posted for tonsillectomy and adenoidectomy.

\section{Exclusion Criteria}

1. Patients of age less than 6 yrs.

2. Children with any other systemic illness.

3. Patients in whom barbiturates or propofol was contraindicated.

\section{Pre-Operative Evaluation}

In all patients the age, body weight, preoperative blood pressure and heart rate were recorded. History regarding previous anaesthesia and surgery and significant medical illness and history of medications and allergy was obtained and excluded.

\section{A Complete Physical Examination}

Of the cardiovascular system, respiratory system, abdomen and central nervous system was done and the airway was assessed. The following screening tests were included -

- Total count.

- Differential count.

- ESR.

- Haemoglobin \%.

- Urine Albumin and Sugar.

- $\quad$ Bleeding time.

- Clotting time.

The Hospital Ethical Committee approved this study and informed consent was obtained from each patient's parent (or) guardian.

On the arrival in the operating room, an intravenous line was secured with a 22-gauge cannula vein and RL infusion was started. The children were premedicated with Inj. Fentanyl 2 microgram/kg and Inj. Glycopyrrolate $5 \mu \mathrm{g} / \mathrm{kg}$ intravenously 5 minutes before the pre-oxygenation.

\section{Monitors Used}

- eTCO2.

- Precordial stethoscope.

- Pulse oximetry.

- $\quad$ ECG monitor lead II.

- Non-invasive blood pressure.

- In the pre-induction period, heart rate, blood pressure and $\mathrm{O}_{2}$ saturation were recorded.

\section{Induction}

Pre-oxygenation with $100 \% \mathrm{O}_{2}$ for 3 minutes. Then all the children were administered $20 \mathrm{mg}$ of Inj. lignocaine intravenously. After pre-oxygenation -

- $\quad$ Group P - 1\% propofol in a dose of $3 \mathrm{mg} / \mathrm{kg}$ was injected over 15 seconds, ${ }^{8)}$ or

- Group T - 2.5\% solution of Thiopentone in a dose of 5 $\mathrm{mg} / \mathrm{kg}$ was injected over 15 seconds.(9)

- Loss of verbal contact was taken as the induction time for propofol.(10),(11)

- Loss of eye lash reflex was taken as the induction time for thiopentone.

After anaesthesia was induced and the face mask applied, natural airway kept patent and patients breathed $100 \% \mathrm{O}_{2} 4$ litres/min through Jackson-Rees' Modifications of Ayre's T piece. The duration of apnoea (apnoea defined as cessation of respiration more than 10 seconds) if any was recorded as the time from the onset of apnoea to the return of spontaneous respiration. Ventilation was assisted if apnoea was greater than 30 seconds or if the arterial saturation fell below $96 \%$.

Tracheal intubation facilitated with suxamethonium 1 $\mathrm{mg} / \mathrm{kg}$ - IV. General anaesthesia was maintained with 4 litres/min of N20:02 mixture with 1\% sevoflurane. Once child recovered from suxamethonium effect, they were administered non-depolarising muscle relaxant Inj. atracurium $0.3 \mathrm{mg} / \mathrm{kg}$ body weight and ventilation controlled. Top up dose of the relaxant was $1 / 3$ of the initial dose was given if necessary.

Any excitatory effects like spontaneous movements, hiccups, laryngospasm, bronchospasm and tremor were noted and cardiovascular variables were measured two minutes after the start of injection of study drugs and repeated every 2 minutes for a period of 10 minutes.

At the end of surgery all patients' neuromuscular blockade was reversed with $0.04 \mathrm{mg} / \mathrm{kg}$ of neostigmine and $0.02 \mathrm{mg} / \mathrm{kg}$ of atropine.

After extubation, children were transferred to Recovery Room, awakening was assessed.

In analysing the data, student's 'L' test chi-squared test with Yates correction for small numbers were used where appropriate.

\section{RESULTS}

\begin{tabular}{|c|c|c|}
\hline Baseline Characteristics & Group P & Group T \\
\hline 1. No. of children & $n=25$ & $n=25$ \\
\hline 2. $\operatorname{Sex} M / F$ & $\mathrm{n}=11 / 14$ & $\mathrm{n}=10 / 15$ \\
\hline 3. Mean age in years & $\mathrm{n}=8.4$ & $\mathrm{n}=8.7$ \\
\hline 4. Age range in years & $n=6-10$ & $n=6-10$ \\
\hline 5. Mean weight in kg & $\mathrm{n}=19.6$ & $\mathrm{n}=22$ \\
\hline 6. Weight range in kg & $n=15-25$ & $\mathrm{n}=15-30$ \\
\hline \multicolumn{3}{|c|}{$\begin{array}{l}\text { Table I. Shows Age, Gender and Weight } \\
\text { Distribution of the Two Groups }\end{array}$} \\
\hline
\end{tabular}




\section{RESULTS}

The mean age, weights and sex of the patients were similar in both groups.

Incidence of Pain on Injection(12),(13)

\begin{tabular}{|c|c|c|}
\hline Apnoea & Group P & Group T \\
\hline Incidence & $\mathrm{n}=3(12 \%)$ & $\mathrm{n}=1(4 \%)$ \\
\hline \multicolumn{2}{|c|}{ Table II. Side Effects During Induction } \\
\hline
\end{tabular}

\section{RESULTS}

The incidence of pain on injection in Group $\mathrm{P}$ was greater $(12 \%)$ than in Group T (4\%) and the difference is statistically significant.

\begin{tabular}{|c|c|c|}
\hline Time in Seconds & Group P & Group T \\
\hline $20-24$ & $\mathrm{n}=3(12 \%)$ & $\mathrm{n}=3(12 \%)$ \\
\hline $25-29$ & $\mathrm{n}=4(16 \%)$ & $\mathrm{n}=5(20 \%)$ \\
\hline $30-34$ & $\mathrm{n}=4(16 \%)$ & $\mathrm{n}=14(56 \%)$ \\
\hline $35-39$ & $\mathrm{n}=6(24 \%)$ & $\mathrm{n}=3(12 \%)$ \\
\hline $40-44$ & $\mathrm{n}=6(24 \%)$ & 0 \\
\hline $45-49$ & $\mathrm{n}=2(8 \%)$ & 0 \\
\hline Total & $\mathbf{n}=\mathbf{2 5}$ & $\mathbf{n}=\mathbf{2 5}$ \\
\hline \multicolumn{3}{|c|}{ Table III A. Induction Time } \\
\hline \multicolumn{3}{|c}{} \\
\hline
\end{tabular}

\begin{tabular}{|c|c|c|}
\hline Time in Seconds & Group P & Group T \\
\hline Mean & $\mathrm{n}=36.8$ & $\mathrm{n}=30.36$ \\
\hline Minimum & $\mathrm{n}=24$ & $\mathrm{n}=20$ \\
\hline Maximum & $\mathrm{n}=48$ & $\mathrm{n}=38$ \\
\hline Sd & $\mathrm{n}=7.9$ & $\mathrm{n}=3.6$ \\
\hline \multicolumn{2}{|c|}{ Table III B. Induction Time (Seconds) } \\
\hline
\end{tabular}

\section{RESULTS}

The mean induction time in Group P was $36.8 \pm 7.90$ seconds and in Group $\mathrm{T}$ was $29 \pm 3.44$ seconds and the difference is not statistically significant.

\begin{tabular}{|c|c|c|}
\hline Apnoea & Group P & Group T \\
\hline Incidence & $\mathrm{n}=10(40 \%)$ & $\mathrm{n}=12(48 \%)$ \\
\hline \multicolumn{3}{|c|}{ Table IV. Apnoea Incidence } \\
\hline
\end{tabular}

10 patients in Group T 40\% and 12 patients (48\%) in Group P developed apnoea. This is not statistically significant.

\begin{tabular}{|c|c|c|c|c|c|c|}
\hline $\begin{array}{c}\text { Time } \\
\text { (min) } \\
\text { after } \\
\text { Induction } \\
\text { and } \\
\text { Intubation }\end{array}$ & $\begin{array}{c}\text { Systolic Arterial } \\
\text { Pressure } \\
\text { (mmHg) }\end{array}$ & \multicolumn{6}{|c|}{$\begin{array}{c}\text { Diastolic } \\
\text { Arterial } \\
\text { Pressure } \\
\text { (mmHg) }\end{array}$} & $\begin{array}{c}\text { Mean Arterial } \\
\text { Pressure } \\
\text { (mmHg) }\end{array}$ \\
\cline { 2 - 7 } & $\begin{array}{c}\text { Group } \\
\text { P }\end{array}$ & $\begin{array}{c}\text { Group } \\
\text { T }\end{array}$ & $\begin{array}{c}\text { Group } \\
\text { P }\end{array}$ & $\begin{array}{c}\text { Group } \\
\text { T }\end{array}$ & $\begin{array}{c}\text { Group } \\
\text { P }\end{array}$ & $\begin{array}{c}\text { Group } \\
\text { T }\end{array}$ \\
\hline 0 & $\mathrm{n}=112$ & $\mathrm{n}=112$ & $\mathrm{n}=70$ & $\mathrm{n}=73$ & $\mathrm{n}=84$ & $\mathrm{n}=86$ \\
\hline 2 & $\mathrm{n}=102$ & $\mathrm{n}=117$ & $\mathrm{n}=65$ & $\mathrm{n}=79$ & $\mathrm{n}=77$ & $\mathrm{n}=91$ \\
\hline 4 & $\mathrm{n}=99$ & $\mathrm{n}=105$ & $\mathrm{n}=63$ & $\mathrm{n}=67$ & $\mathrm{n}=75$ & $\mathrm{n}=79$ \\
\hline 6 & $\mathrm{n}=96$ & $\mathrm{n}=103$ & $\mathrm{n}=61$ & $\mathrm{n}=65$ & $\mathrm{n}=72$ & $\mathrm{n}=78$ \\
\hline 8 & $\mathrm{n}=93$ & $\mathrm{n}=100$ & $\mathrm{n}=59$ & $\mathrm{n}=64$ & $\mathrm{n}=71$ & $\mathrm{n}=76$ \\
\hline 10 & $\mathrm{n}=91$ & $\mathrm{n}=99$ & $\mathrm{n}=58$ & $\mathrm{n}=62$ & $\mathrm{n}=69$ & $\mathrm{n}=74$ \\
\hline
\end{tabular}

Table V. Mean Values for Systolic, Diastolic and Mean Arterial Pressures Before and After Induction and Intubation with Propofol (P) or Thiopentone (T),(14),(15),(16)

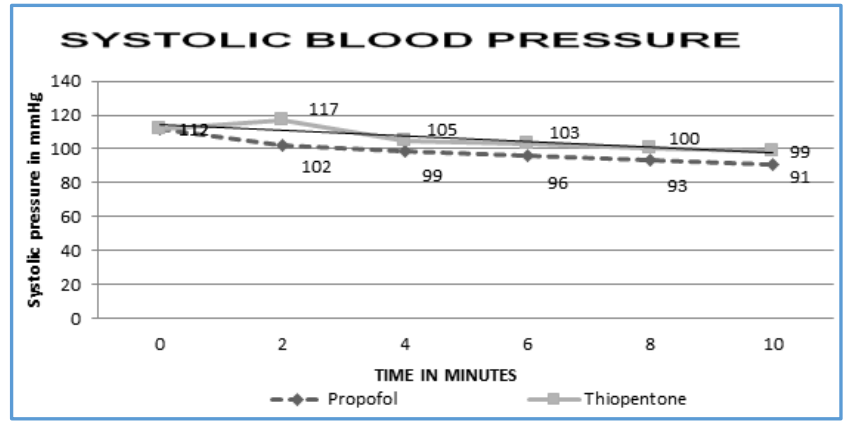

In Group T, mean systolic pressure increased from $112 \pm$ $4.8 \mathrm{mmHg}$ to $117 \pm 4.2 \mathrm{mmHg}$ during the second minute and $99 \pm 3.2 \mathrm{mmHg}$ at $10^{\text {th }}$ minute.

In Group P, mean systolic pressure reduced from $112 \pm 4.8$ $\mathrm{mmHg}$ to $102 \pm 4.4 \mathrm{mmHg}$ during the second minute and $91 \pm$ $2.8 \mathrm{mmHg}$ at $10^{\text {th }}$ minute and the reduction is statistically significant (Table V).

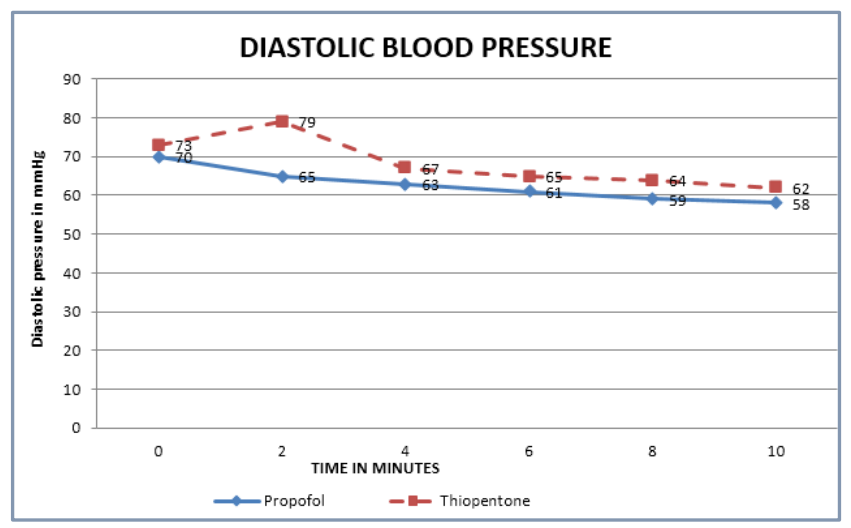

Following induction and intubation, the mean diastolic pressure in Group T increased from $73 \pm 4.7 \mathrm{mmHg}$ to $79 \pm 4.3$ $\mathrm{mmHg}$ in the second minute and $62 \pm 3.2 \mathrm{mmHg}$ in the $10^{\text {th }}$ minute.

In Group P, the mean diastolic pressure fell from $70 \pm 4.6$ $\mathrm{mmHg}$ to $66 \pm 4.8 \mathrm{mmHg}$ in the second minute and $58 \pm 2.2$ mmHg in the $10^{\text {th }}$ minute.

The fall in mean diastolic pressure was greater in Group $P$, is statistically significant $(\mathrm{P} \leq 0.01)$.

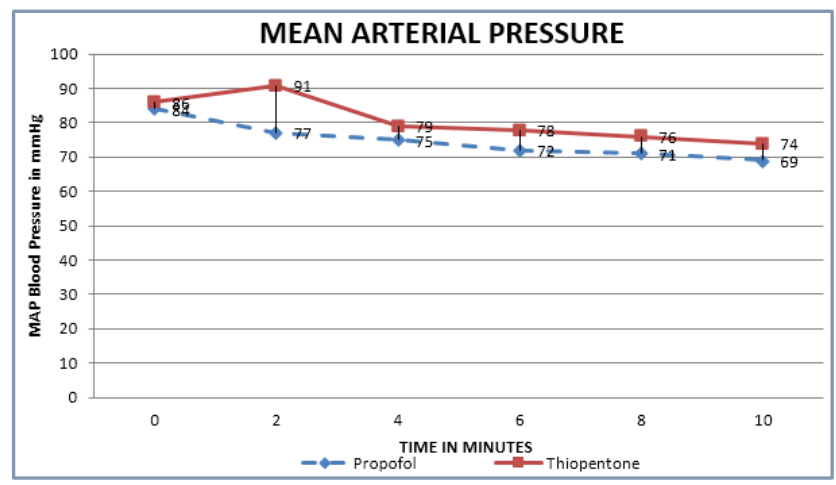

Mean arterial pressure in Group T increased from $86 \pm 4.7$ $\mathrm{mmHg}$ to $91 \pm 4.6 \mathrm{mmHg}$ in the second minute. In Group P, the mean arterial pressure fell from $84 \pm 4.6 \mathrm{mmHg}$ to $77 \pm 5.2$ $\mathrm{mmHg}$ in the second minute. 
The fall in mean systolic pressure in Group P is statistically significant $(\mathrm{P}=0.01)$.

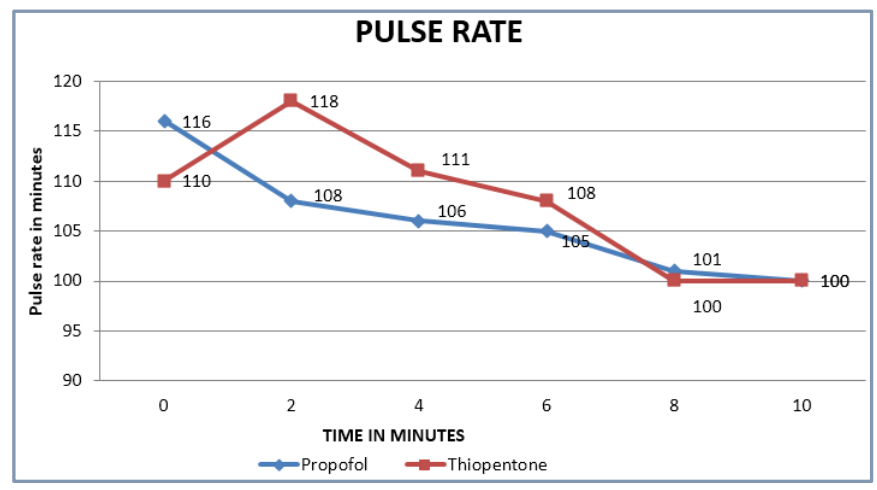

The pre-induction mean pulse rate Group T was $110 \pm 4.5$ per minute, while pre-induction mean pulse rate Group P was $116 \pm 4.7$ per minute.

The mean pulse rate in Group P reduced to $108 \pm 4.6$ per minute in the second minute and gradually reached $100 \pm 4.4$ per minute in 10 minutes.

The mean pulse rate in Group T increased to $118 \pm 4.4$ per minute in the second minute and gradually reached $100 \pm 3.2$ per minute in 10 minutes.

The mean decrease in pulse rate in Group P is statistically significant $(\mathrm{P} \leq 0.01)$.

\section{DISCUSSION}

Anaesthesia induction is commonly initiated by an Intravenous (IV) administration of hypnotics, such as thiopental or propofol for abruptly bringing wakeful patients into unresponsiveness to strong adrenergic stimuli including tracheal intubation and surgical procedures. However, haemodynamic instability in various degrees is commonly associated during the anaesthesia induction phase using these hypnotics. Patients experienced severe hypotension during and after anaesthesia induction in clinical practice. Hypotension often occurs after IV thiopental and propofol in patients with Left Ventricular (LV) dysfunction.

Unfortunately, even though LV systolic function is one risk factor for anaesthesia induction events and it is well known that induction has significant haemodynamic and cardiac effects, the kind and magnitude to the effects on LV myocardium function of anaesthesia induction including the particular agents used have not been thoroughly studied. This may be due to the routineness and apparent harmlessness of the effects as observed casually and also a lack of monitoring tools and procedures.

Considering that thiopental and propofol are the two most popular and widely used IV anaesthesia induction agents, we compared the induction characteristics of propofol and thiopentone in ENT surgery in children.

Pain on injection with propofol is a common problem. In children, the incidence of pain varies between $28 \%$ and $85 \%$.(17) The incidence of pain on induction with thiopentone is about 7\%. In our study, the incidence of pain in Propofol Group was $12 \%$ and in Thiopentone Group was $4 \%$.

There will be increase in heart rate and blood pressure whenever intubation is attempted due to laryngeal reflexes and psychological stress. Many drugs have been tried to attenuate these stress response. We compared the haemodynamic changes following induction with propofol and thiopentone.

The following parameters were compared - Onset time, Pain and Haemodynamic variables like Heart rate and Blood pressure.

We found that onset time was similar in both groups.

The reduction in mean arterial pressure was significantly greater after propofol $(28 \%-31 \%)$ than after thiopentone $(14 \%-21 \%)$.

In our study, we found the fall in mean systolic and diastolic pressure was greater in patient who received propofol than with thiopentone. It was also found to be statistically significant.

Also in our study, we found the mean decrease in pulse rate was more in patients who received propofol than those who received Thiopentone, which was found to be statistically significant.

\section{CONCLUSION}

For both induction agents, Thiopentone and Propofol, the onset time was similar. Induction with Propofol produced a significant fall in haemodynamic variables like heart rate and blood pressures than Thiopentone.

\section{REFERENCES}

1. Aitkenhead AR, Smith G. Text book of anaesthesia. Intravenous anaesthetic agents. $2^{\text {nd }}$ edn. 1994:175-83.

2. Atkinsom RS, Rushman GB, Davies NJH. Lee's synopsis of anaesthesia. $11^{\text {th }}$ edn. Butterworth-Heinemann 1993:157-75.

3. Borgeat A, Popovic V, Meier D, et al. Comparison of propofol and thiopental / halothane for short duration ENT surgical procedures in children. Anaesthesia Analgesia 1990;71(5):511-5.

4. Aun CS, Sung RY, O'Meara ME, et al. Cardiovascular effects of intravenous inductions in children: comparison between propofol and Thiopentone. British Journal of Anaesthesia 1993;70(6):647-53.

5. Acalovschi I, Miclescu A, Bugov L, et al. The effects of Propofol on laryngeal reactivity and the hemodynamic response to laryngeal mask insertion. European Journal of Anaesthesiology 1995;12(4):351-6.

6. Brossy MJ, James MF, Janicki PK, et al. Hemodynamic and catecholamine changes after induction of anaesthesia with either thiopentone or propofol with suxamethonium. British Journal of Anaesthesia 1994;72(5):596-8.

7. Cvejanoc M, Pejakov L, Marincovic S, et al. Propofol in general anaesthesia in children. Med Pregl 1993;46(910):353-6.

8. Hannallah RS, Baker SB, Casey W, et al. Propofol: effective dose and induction characteristics in unpremedicated children. Anaesthesiology 1991;74(2):217-9.

9. Hannallah RS, Britton JT, Schafer PG, et al. Propofol anaesthesia in paediatric ambulatory patients: a comparison with thiopentone and halothane. Canadian Journal of Anaesthesia 1999;41(1):92-8.

10. Jones RD, Visram AR, Chan MM, et al. A comparison of three induction agents in paediatric anaesthesia. Cardiovascular effects and recovery. Anaesthesia \& Intensive Care 1994;22(5):545-5. 
11. Manschot HJ, Meursing AE, Axt $P$, et al. Propofol requirements for induction of anaesthesia in children of different age groups. Anaesthesia Analgesia 1992;75(6):876-7.

12. McCulloch MJ, Lees NW, et al. Assessment and modification of pain on induction with propofol (Diprivan). Anaesthesia 1985;40(11):1117-20.

13. Nightingale P, Healy TE, Hargreaves J, et al. Propofol in emulsion form: induction characteristics and venous sequalee. European Journal of Anaesthesiology 1985;2(4):361-8.

14. Brown RE. Paediatric outpatient anaesthesia. In: Motoyama EK, Davis PJ. eds. Smith's anaesthesia for infants and children. $6^{\text {th }}$ edn. St. Louis: Mosby 1996: 709-22.
15. Purcell-Jones G, Yates A, Baker JR, et al. Comparison of induction characteristics of thiopentone and propofol in children. British Journal of Anaesthesia 1987;59(11):1431-6.

16. Saarnivaara L, Hiller A, Oikkonen M, et al. QT interal, heart rate and arterial pressure using propofol, thiopentone or methohexitone for induction of anaesthesia in children. Acta Anaesthesiological Scandinavica 1993;37(4):41923.

17. Valtonen M, Iisalo E, Kanto J, et al. Comparison between propofol and thiopentone for induction of anaesthesia in children. Anaesthesia 1988;43(8):696-9. 